\title{
THE CAUSES OF THE WAR IN CURRENT TRADITION
}

\author{
By W. T. WAUGH.
}

IN a recent public examination, the History paper contained the question, "Why did the German Government provoke war in 1914?" The candidates were boys and girls of fifteen or sixteen, and came from various parts of the north and midlands. Their object was to qualify for admission to a teachers' training college, and it may be presumed that they were among the most intelligent and successful pupils in their respective schools.

Very few candidates attempted the question, and those that did generally limited themselves to a bald summary of what they believed to be the events of July and August, 1914. The answers were mostly inaccurate and uninstructive, and several revealed nothing but astonishing ignorance. Two, or three, however, have some claim to the attention of those interested in the systematic study of testimony. They should, in my opinion, be regarded as products of oral tradition, for in 1914 the writers were not old enough to understand the momentous events which were taking place, and their present knowledge of them is probably based for the most part on what they have heard from teachers or parents.

The three following passages seemed specially instructive, and worthy of being quoted at length. Each is from a different candidate:

(1) "Germany thought that if she broke what was called the "Scrap of Paper,' she would be able to attack England more easily. The treaty which she was breaking said that Germany could not use Belgium as a means of transporting troops in time of war. The breaking of the treaty annoyed France as well as Belgium so she allied with Belgium against Germany....England saw that if she did not help France and Belgium, Germany would more easily be able to attack her when she had conquered France, so England joined France and Belgium. These three allies were known as the Triple Entente." The sequel concerns the murder of the Archduke Franz Ferdinand; it is generally true to fact and calls for no special remark.

(2) "Kaiser Wilhelm II... wished to strike at England and so attacked Belgium and took Alsace-Lorraine-two states which were given to Germany at the close of the Franco-Prussian war, 1871, but which being French states were given back to France later on, by the wish of the 


\section{The Causes of the War in Current Tradition}

people. After ravaging Belgium the Germans attacked the northern borders of France. England was allied with France and so went to her aid. This brought about the thing that Germany wanted, i.e., war with England."

(3) "The Serbian Crown Prince was murdered by an Austrian, so Serbia declared war on Austria. Russia was bound to help Serbia since it was to her own advantage, and Germany stood by Austria. Then France had to join in with Serbia and Russia because of her long and bitter hatred of Germany, thinking she would retaliate for the Franco-Prussian war of 1870 . To invade France, Germany would have to cross through Belgium, and though she was warned not to by the other powers she still persisted in doing so, and England was in honour bound to protect Belgium." What follows reveals a fairly accurate knowledge of the principal treaty which guaranteed Belgian neutrality.

These extracts, with the evidence afforded by other papers, show plainly that, even before the war was formally ended, the rising generation had utterly confused notions of how it began. The political significance of this, though serious, cannot be discussed here. The problem for the psychologist is to analyse and explain the distortions of fact which mark the three passages quoted and indeed all the answers to the question. Their main source is evident-namely, a desire, unconscious it may be, to make things easy, and in particular to bring the events narrated into obvious harmony with certain fundamental assumptions. It was generally taken for granted by the candidates (a) that Germany was in the wrong, (b) that Germany was the aggressor, $(c)$ that Germany's main object was the overthrow of England. These three postulates were clearly accepted by the writers of extracts (1) and (2) quoted above; the writer of extract (3) accepted postulate $(a)$ and, so far as Belgium and England were concerned (b) also, but does not seem to have been affected by $(c)$. A very interesting illustration of the influence of postulate $(a)$ is afforded by the remarkable inversion of the facts that occurs in the first sentence of extract (3). The writer knew that the murder of the heir to a European throne marked the beginning of the crisis. She had no doubt that Germany was the villain of the drama that followed. Therefore the murderer must have been, if not actually a German, a subject of one of Germany's allies in the war, and the victim a subject of one of her enemies. Similarly, the astonishing statement about Alsace-Lorraine in extract (2) seems to be due to the influence of postulate $(b)$. If Germany was the greedy aggressor, how came it that, at the end of the war, she had to surrender some of her own territory to a state which (ex hypothesi) had been fighting in self- 
defence? Why, because Alsace and Lorraine had belonged to France at the outbreak of war, and, like Belgium and north-east France, had been overrun by the German invaders. But the writer could not forget that Alsace and Lorraine had been annexed by Germany in 1871, and she therefore had to invent a subsequent cession of the provinces to France, the principle of self-determination being ingenuously called in to lend an air of verisimilitude to the story. It is not surprising that she was confused, for the terms of peace are supposed to have involved "no annexations," and in public discussion Alsace and Lorraine have commonly been treated as if they were on precisely the same footing as Belgium.

The third assumption - that Germany's main object was the overthrow of Britain-exercises a strong influence on extracts (1) and (2). The writers evidently felt that Germany's principal motive must have affected her conduct of the war from the outset, and they accordingly adduce it to explain the violation of Belgium neutrality, though how this was expected to promote the destruction of Britain is not made clear. It appears, in fact, that none of the candidates really understood the significance of the invasion of Belgium. Of those cited above, the first two failed to realise that it was the immediate cause of Britain's entry into the war; and the third, while grasping the idea of neutrality and the obligations of Britain towards Belgium, was led away by her ignorance of geography from the true explanation of Germany's action. But in each case, it should be emphasized, the version presented is simpler than the actual facts. In the first two extracts Germany invades Belgium because such a course will directly serve her object of destroying Britain; in the third she does so because there is no other way of getting at France. Either explanation is much easier to understand than the strategic plans of the German General Staff.

The same tendency towards simplification is revealed by the reluctance with which the candidates touched upon the predisposing causes of the war. Few of them felt sure of their ground when they ventured further back than the murder of the Archduke, and most tried to indicate that the events of the last few weeks before the war were sufficient to account for what followed. The writer of extract (1), indeed, goes so far as to make the formation of the Triple Entente a consequence of the invasion of Belgium.

Of course some of the misapprehensions and omissions of the candidates are due to merely fortuitous influences and possess no interest for the scientific student of evidence. The cynicism of extract (3) is probably unconscious, the writer, one may suggest, having imperfectly 


\section{The Causes of the War in Current Tradition}

grasped a lesson given by some teacher of judicial temperament. Very interesting, on the other hand, is the treatment of the "scrap of paper" phrase in extract (1) - a complex instance of a process familiar to all historians, whereby a word or phrase used originally in scorn or irony loses its sting and acquires an inoffensive or even honourable significance ${ }^{1}$. The disappearance of Russia from the Triple Entente-another notable feature of this passage - is natural in view of recent events; it is a further example of harmonization, only in this case the criterion is the situation at the time when the examination was held. It is, however, astonishing that Italy is not named as a party. Apparently the writer knew more about the course of the war than a first reading of her answer might lead one to suppose-a wholesome reminder that most people's memories are capricious to a degree that is seldom realised even by trained investigators of evidence.

It may be urged that the interest of the passages quoted is vitiated by the fact that they were written by children, who, however intelligent, lacked the experience and knowledge essential to a comprehension of international politics, and that grown men and women, even though their information had been derived from precisely the same sources, would have answered the question very differently. That may well be; but it is extremely doubtful whether they would have answered it any better. For there is much to be said for the view that boys and girls in the higher forms of our secondary schools are in general keener on knowledge, more "gleg in the uptake," more critical, and better-informed on matters outside their everyday experience, than the majority of their adult compatriots, while there can be no question as to the normal superiority of their memories. And, in comparison with most of the witnesses on whom, in the last resort, our knowledge of history depends, they have all the advantages just enumerated, together with a faculty of expression which, until the present age, was possessed by few. If, in short, allowance ought to be made for the youth of the writers whose work we have been considering, it is because, as witnesses, they are likely to be above the average.

1 Well-known examples are the terms Whig, Tory, Methodist, Quaker. But their development is relatively simple, and $I$ cannot recall a case quite parallel to the one before us. The phrase was first used by Bethmann-Hoilweg in contempt, then taken up by Germany's enemies and used in irony, and now, it appears, there is a possibility of its becoming regarded as the name by which, even before the war, the Treaty of London of 1839 was commonly known.

(Manuscript received 23 June 1920.) 